九州大学学術情報リポジトリ

Kyushu University Institutional Repository

\title{
An Improved Method For The Preparation Of Glycine
}

Sasaki, Shuiku

Laboratory of Sericulture Chemistry, Faculty of Agriculture, Kyushu University

Watanabe, Tadao

Laboratory of Sericulture Chemistry, Faculty of Agriculture, Kyushu University

Inagami, Kaoru

https://doi.org/10.5109/22632

出版情報 : 九州大学大学院農学研究院紀要. 9 (3)，pp.283-285，1950-01. Kyushu University バージョン：

権利関係 : 
Journal of the Faculty of Agriculture, Kyūshū University, Vol. 9, .No. 3 January 31, 1950

\title{
AN IMPROVED METHOD FOR THE PREPARATION OF GLYCINE
}

\author{
Shuiku Sasaki, Tadao Watanabe and Kaoru Inagami
}

The classical method of preparing glycine from monochloroacetic acid and ammonia (1) has been improved by several investigators $(2,3,4)$, but proved generally unsatisfactory. One of the defects is the contamination with large amounts of normal by-product of ammonium chloride, and side reaction products of diglycine and triglycine, which hinder the crystallization and purification of glycine. After much surveying and comparing, we found a simple method for the isolation of pure glycine at a high yield.

The reaction mixture, in which a 60 to 1 molar ratio of ammonia to monochloroacetic acid was employed, was concentrated to crystallize the main portions of glycine and ammonium chloride. After cooling, the precipitate was filtered, and washed with a little amount of cold water. In this way we could separate syrupy diglycine and triglycine almost perfectly from the crystalls. It was proved that very little glycine escaped in the filtrate.

Robertson (2) states "It seems reasonable that either the di-acid or the tri-acid might make a mixture salt or amide with both glycine and ammonia, thus making the impurity persistent in material of low solubility...............Its principal role is that of interfering with the crystallization of glycine and of contaminating the product." On examining our experiments, however, we found that glycine and ammonium chloride in the solution did not combine with diglycine and triglycine to a complex mixture.

For the purpose of isolating glycine from the mixture of glycine and ammonium chloride, magnesium oxide was added to the solution of the mixture. 


$$
\mathrm{MgO}+2 \mathrm{NH}_{4} \mathrm{Cl}=2 \mathrm{NH}_{3}+\mathrm{MgCl}_{2}+\mathrm{H}_{2} \mathrm{O}
$$

Since magnesium oxide is insoluble in water, magnesium chloride very soluble in strong alcohol (about $50 \%$ ), and glycine sparingly soluble in strong alcohol (about $0.2 \%$ ), we could easily isolate glycine in a pure state using the different solubilities of these substances.

As was suggested by Robertson (2), most investigators have used $60 \mathrm{mols}$ of ammonia and $1 \mathrm{~mol}$ of monochloroacetic acid. We compared our method with the methods of 'several investigators.

Table 1 .

\begin{tabular}{|c|c|c|c|}
\hline Author & $\begin{array}{l}\text { Molar ratio of ammonia } \\
\text { to monochloroacetic acid }\end{array}$ & $\begin{array}{l}\text { Reagents for } \\
\text { separation }\end{array}$ & $\begin{array}{l}\text { Yield of } \\
\text { glycine of the } \\
\text { theoretical }\end{array}$ \\
\hline Roibertson & $60: 1$ & $\begin{array}{l}\text { Silver oxide } \\
\text { and methanol }\end{array}$ & $50 \%$ \\
\hline $\begin{array}{l}\text { Boutwell and } \\
\text { Kuick } \\
\text { Urten and Hill }\end{array}$ & $\begin{array}{l}60: 1 \\
60: 1\end{array}$ & $\begin{array}{l}\text { Pyridine and } \\
\text { methanol } \\
\text { Methanol }\end{array}$ & $\begin{array}{l}54 \\
60-64\end{array}$ \\
\hline Sasaki and al. & $60: 1$ & $\begin{array}{l}\text { Magnesium oxide } \\
\text { and ethanol }\end{array}$ & 76 \\
\hline
\end{tabular}

According to Robertson(2), the molar ratio of ammonia to monochloroacetic acid used and actual amount of glycine formed were as follows.*

Täble 2.

\begin{tabular}{l|c|c|c|c|c|c|c}
\hline $\begin{array}{l}\text { Molar ratio of ammonia to } \\
\text { monochloroacetic acid }\end{array}$ & $2: 1$ & $4: 1$ & $6: 1$ & $15: 1$ & $24: 1$ & $60: 1$ & $220: 1$ \\
\hline $\begin{array}{l}\text { Primary amine produced } \\
\% \text { of theoretical }\end{array}$ & 29 & 32 & 37 & 58 & 65 & 86 & 95 \\
\hline
\end{tabular}

\section{EXPERIMENTAL}

One mol (94.5 g.) of monochloroacetic acid was dissolved in 4 liters of ammonium hydroxide (sp. gr. 0.90) in a stoppered bottle at a room temperature for two days. The excess of ammonia

* The mechanism and kinetics of glycine synthesis are now under investigation. 
was distilled off and recovered. The solation was concentrated under reduced pressure until most of glycine and ammonium chloride were crystallized out. After cooling, the precipitate was filtered with Büchner funtel, pressed well, and washed with a small amount of cold water. The filtrate and washing were combined, concentrated and crystallized again.

The combined precipitates were dissolved in water, and the solution boilcd by adding about $20 \mathrm{~g}$. of magnesium oxide. After the odor of ammonia has vanished, excess of magnesium oxide, if presented, was filtered off and neutralized with hydrochloric acid. The filtrate was concentrated to almost dryness. The glycine was separated out by gradually adding, with stirring, $500 \mathrm{cc}$. of $95 \%$ alcohol. The mixture was filtered, and washed with $95 \%$ alcohol until the filtrate did not contain chlorine ion by testing with silver nitrate. The precipitate, consisting almost pure glycine, was recrystallized with water. The yield was $56.7 \mathrm{~g}$. (theoretical $75.6 \%$ ). The product was free from chloride by testing with silver nitrate, and ammonium ion by testing with Nessler's solution. Ash content was less than 0.01\%. It melted at 235$237^{\circ}$, and showed the theoretical percentage of nitrogen.

\section{SUMMARY}

For the preparation of glycine from monochloroacetic acid and ammonia, we have succeeded to obtain pure glycine at a high yield by excluding the by-product of ammonium chloride and the side-reaction products of diglycine and triglycine by magnesiaalcohol method.

We are indebted to the Grant of Scientific Research of Department of Education for this investigation.

\section{REFERENCES}

(1) Kraut, K., Ann., 226, 292 (1891).

(2) Robertson, G. R., J. Am. Chem. Soc., 49, 2889 (1927).

3) Boutwell, P. W., and Kuick, L.F., J. Am. Chem. Soc., 52, 4166 (1930).

(4) Orten, I. M., and Hill, R. M., J. Am. Chem. Soc., 53, 2797 (1931). 